\section{Ultralydsymposium 2012 i Stavanger}

Fra 14. til 16. mars 2012 avholdt NFUD sitt 36. årlige symposium i Stavanger. Styret hadde satt sammen et variert fagprogram på høyt nivå og arrangementskomitéen med Claudia Heien i spissen sørget for et velegnet møtested og ikke minst underholdende innslag under åpningen og festmiddagen. 123 registrerte deltagere tyder på vedvarende interesse for foreningens tilbud, og er på høyde med deltakelsen ved fjorårets symposium i Trondheim.

I god tradisjon ble det en rekke foredrag om teknikken bak ultralyd og praktisk bruk av ultralyd både for mer og mindre erfarne ultralydbrukere. Også praktiske øvelser og live-demonstrasjoner ble godt mottatt.

\section{Flere internasjonale foredragsholdere $\nabla$}

Søren Torp-Pedersen er en etterspurt foreleser innen ultralyddiagnostikk av muskel- og skjelettlidelser. Han gav ikke bare en oversikt over Dopplerultralyd som diagnostisk redskap ved revmatoid artritt, men holdt også et avklarende foredrag om bruk av Power Doppler i forhold til farge Doppler.

Kurt Hecher fra Hamburg er en av de mest rutinerte behandlere internasjonalt av monochoriote tvillinger med føtoføtalt transfusjonssyndrom med over 1000 fetoskopiske laserbehandlinger. Norge har i flere år sendt slike tvillingsvangerskap til Hamburg, og Birgitte Kahrs fra Nasjonalt Senter for Fostermedisin presenterte forløp og resultater av samarbeidet. Tallene for norske tilfeller er nærmest identiske med de samlede resultatene Kurt Hecher viste.

Dieter Nürnberg er gastroenterolog med mangeårig erfaring i ultralydbaserte avbildningsmetoder og intervensjoner. Han oppdaterte tilhørere om perfusjonsavbildning med kontrastforsterket ultralyd av abdominale organer, spesielt nyre- og binyre. Han åpnet også andre møtedagen med foredrag om ultralyd i akuttmedisin.

\section{Ultralyd i akutt- og intensivmedisin \\ $\nabla$}

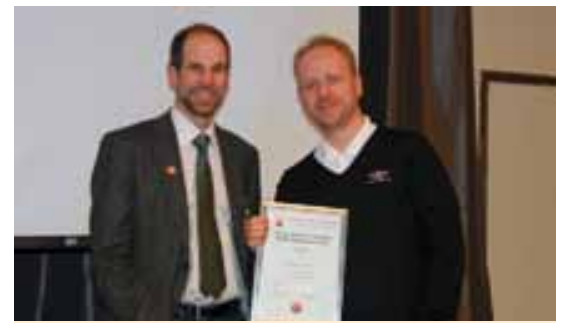

Fig. 1 Styreleder Roald Flesland Havre overrekker pris for beste frie foredrag til Nils Petter Oveland.

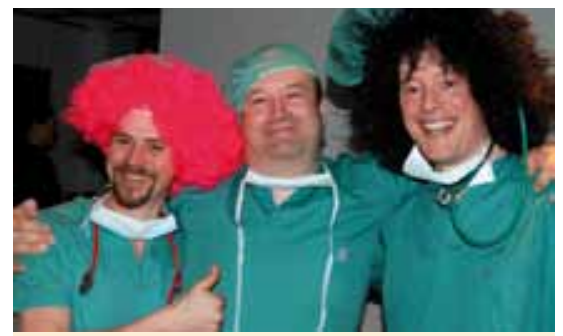

Fig. 2 Obstetriske menn.

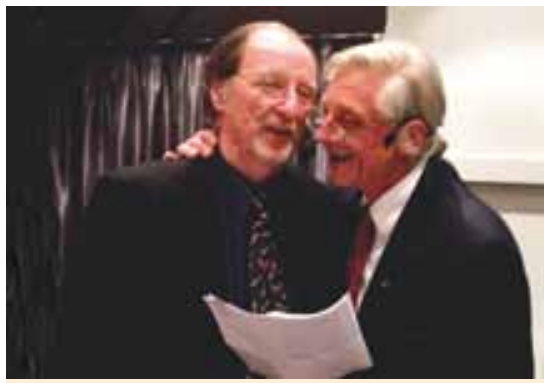

Fig. 3 Takk-for-maten tale og NFUDs historie ved Svein Ødegaard og Sturla Eik-Nes.

Ultralyd i akuttmedisin var i år for første gang temaområde på symposiet og fikk en engasjert og vellykket start. FAST (Focused Assessment with Sonography for Trauma) og FATE (Focus Assessed Transthoracic Echo) innebærer rask og målrettet undersøkelse av perihepar, perisplen, pelvis, perikard og thorax.

Erik Sloth er en foregangsmann for ultralyd i akutt- og intensivmedisin og internasjonalt anerkjent foredragsholder. Han fremstilte metoden på en svært fengende og overbevisende måte og la vekt på fordeler i forhold til mer effektiv pasientbehandling.

\section{Pris for beste frie foredrag} $\nabla$

Nils Petter Oveland, anestesilege ved Stavanger Universitetssykehus og stipendiat ved Norsk Luftambulanse fikk prisen for beste frie foredrag på kr 10.000. Tittelen var: "Ultrasound detection of pneumothorax: Animal laboratory training improves diagnostic competency and speed".

Både faglige og sosiale aktiviteter fikk plass og ultralydapparatene i utstillingen var godt besøkt. Stemningen på festmiddagen var god. De "The Trionettas» viste oss, hvordan akutt fødselshjelp i Stavanger foregår, mens "Obstetriske menn» holdt stemningen musikalsk oppe. Kollegaene i Stavanger fortjener all ære for en virkelig flott underholdning.

To av våre æresmedlemmer, Sturla EikNes og Svein Ødegaard stod for takk-formaten tale og beskrev NFUDs 35-årige historie på en livlig og underholdende måte. Årets symposium anses som både faglig og sosialt vellykket, noe som også kom frem i evalueringen fra deltakerne.

Vi ser frem til neste års symposium i Sandefjord fra 17. til 19. april 2013.

\section{For styret}

Peter Montzka 